\title{
An Analysis of the Contributions of Taboo System to Peace among Shona Communities in Zimbabwe
}

Dr Norman Chivasa

Adjunct Lecturer, Southern Institute of Peace Building and Development, Zimbabwe Open University Zimbabwe

Mr Andrew Mukono

Lecturer, Zimbabwe Open University, Zimbabwe

\begin{abstract}
People's attitudes and behaviour are often influenced by tradition, religion and modernity. The taboo system among the Shona communities is a typical example of how tradition over the years has played a critical role in shaping individual and group behaviour. This paper is based on insiders' participant observations and literature sources. Results showed that the problem of electoral violence calls for more than just efforts by government to enforce law and order to address this menace but an appeal to the taboo system which is not based on law enforcement agents but respect for the in-born humanitarian seed. In addition, the findings indicate that the emergence of electoral violence in the 2008's harmonized elections in Zimbabwe indicates a shift from what Shona society historically accepted as normal. Also it came out clear that electoral violence is symptomatic of the disregard of the taboo system by modern Shona communities making them ease prey to political manipulation by some political elites. The study recommended that, in this age where violence is seemingly becoming humanity's second nature, the taboo system has the potential to effectively promote and sustain peace among the Shona communities in Zimbabwe.
\end{abstract}

Keywords: Community, violence, taboo system, peace and Zimbabwe

\section{INTRODUCTION AND BACKGROUND}

During the presidential run-off election on June 27, 2008, the dominant cultural group, the Shona people of Zimbabwe was drawn into electoral violence not because they were violent. They did not turn out violent overnight. It was after the traditional Shona society had shown itself amazingly resilient for several decades spanning from 1890 to 2008 but fell victim along the way to transitional forces such as colonialism, the protracted conflict and the changing political terrain which gripped this particular society (Kabweza, 2002).

Conventionally, election violence in Zimbabwe has been endorsed as the breakdown of democratic principles (Fischer, 2002; Teshome, 2009; Tadjoeddin, 2011). This view overlooks the progressive breakdown of tradition, in particular, the taboo system as a violence deterring mechanism which can be traced to as far back to the pre-colonial era. The current paper argues that in post independence Zimbabwe electoral violence was symptomatic of the deterioration of peaceable traditions, in particular the taboo system which sustained Shona society for several decades.

Previous studies, for example, Alexander and Tendi (2008); Reeler (2008); SITO (2008); Bamfo (2010) found out that the inherited culture of impunity (from the Smith regime) compounded by political intolerance and adversarial political relations were some of the major factors that exacerbated election violence in Zimbabwe. As a result, these studies have proposed that the government of Zimbabwe should play a leading role in addressing the impact of election violence of 2008. In line with these proposals, the government of Zimbabwe has set up the organ on national healing, reconciliation and integration commission (ONHRI) in 2009 to spearhead the healing process involving victims of election violence of 2008. ONHNRI culminated into the National Peace and Reconciliation Commission in 2014. Its objectives and scope are beyond the scope of this paper.

In the same vein, civic organizations have also taken an active role through forums, workshops, meetings and conventions to lobby for transitional justice as a way of addressing the legacy of election violence of 2008. The most notable was the Zimbabwe Human Rights NGO Forum (ZHRNF) 
a coalition of 19 human rights organizations since 1998, which works with people at grassroots level. The contention of the current paper is that the legacy of election violence of 2008, demands a bottomup approach to abate its consequences because electoral violence was community-based. This bottom up approach should focus on the revitalization of institutions that help to shape the behaviour of individuals and groups at community level. Institutions that are bent on influencing human behaviour are more sustainable in terms of promoting peace. By way of example, this paper has singled out the taboo system as one of the mechanisms that can help to mitigate violence because of its propensity to deter violence at community levels.

Among the Shona, taboos have been passed down from one generation to another even before the colonial era (Chigidi, 2009). Mapara (2010) asserts that among the Shona taboos have "evolved from [their] intimate knowledge of the world that they lived in prior to the advent of colonization and Christianity which taught that some of the Shona knowledge forms were paganism or heathenism." These taboos served as codes of conduct meant to control, guide and regulate human behaviour (Mawere and Kadenge, 2010). It can thus be deduced that taboo system was one of the social control mechanisms that was bent on influencing human behaviour in line with the norms and values of the Shona peoples. As Gelfand (1965:87) and Fortune (1980:ii) note "Shona social norms and values do not encourage violence, the worship of strength, speed or fighting between human beings. Their underlying value is peace." This explains why this paper sought to analyze the contributions of the taboo system to peace in Shona communities with a view to revitalize this social control mechanism for the benefit of modern communities.

\section{CONCEPTUAL FRAMEWORK}

Violence is a contested concept. Nevertheless, this paper adopts the maximalist and minimalist approach to the concept of violence. Contemporary theorists argue that there are two approaches to understanding the concept of violence: the minimalist and maximalist approaches (Bufacchi, 2005). The minimalist looks at violence in terms of the use of force. Under this approach, violence relates to coercion or the exercise power over someone/ something. This category of violence is code named: loud violence which refers to the use of force against people and their property as opposed to silent violence which denotes force used against livestock/ environment (See Watts (1985) cited in Chitiyo, 2000).

The maximalist approach defines violence in terms of violation. Bowman (2001) describes violation as infringement, transgression, outrage, breaking a code of conduct, dishonouring and abuse. In other words, violation denotes the infringement of the rights of persons (such as encroachment of human autonomy, body and dignity) (see Garver cited in Bufacchi, 2005).

What is clear from the two approaches is that violence is not only limited to the use of force, coercion or aggression, but it involves the intrusion of existing state of affairs, rights of people and dignity which result in a crisis which is violation by another name. In that sense, as evidence suggests violence can vary from injury, death, psychological harm, mal-development or deprivation. This paper is more interest in murder as a form of violence and among the Shona taboo system was one of the deterring mechanisms for murder for several decades.

A taboo can be thought of in terms of "a cultural or religious custom that forbids people to touch, use or mention or do certain things or words" (Kilonzo et al 2009:41). As a cultural custom, taboos belong to the non-material component of the Shona culture and they formed part of the Shona people's "well-conceived system of morals" (Chimuka, 2001:28).

According to Gelfand (1999), taboos are avoidance rules (zviera) whose sole purpose is to guide and regulate human behaviour. Murder in this paper is construed as a learned behaviour by the perpetrator. In the words of Tatira (2000: v): “...taboos helped in that they instilled fear in would-be deviants that if they misbehaved misfortunes such as illnesses, deformities or death would befall them". As a result many old Shona people avoided wilful killing of people because they were socialized through the taboo system that: "if a person is wilfully killed, his spirit will come back to haunt the killer and his relatives" (Masaka and Chemhuru, 2011:134). The role of spirits in haunting the killer is beyond the scope of this paper. However, the important thing to note is that the fear to kill someone helped to regulate non-violent social interaction which is an important aspect for peaceful co-existence between individuals and community members. Peaceful co-existence is one of the key aspects of peace in any community. 


\section{LITERATURE REVIEW}

The concept of peace among the Shona is closely linked to their cosmology. According to Chimuka Shona people are a cosmologically oriented people. They assume that the natural world was created by Musiki (the most powerful Spiritual being who created the heavens and the earth and sustains all things). They assert that human beings were created by Musikavanhu (He who created humankind) (2001: 29). Thus, in the traditional Shona cosmovision it is assumed that: "the human world, the natural world and the spirit world are linked" (Haverkort et al, 2003:142). It is the spirit world and its links to the concept of peace that is of interest to this paper.

A Shona household is the basic social unit which involves both surviving relatives and the ancestral spirits. Ancestral spirits are considered the founders of a household unit and therefore play an important role in the behaviour of each member of household towards one another (Gelfand, 1999). Nevertheless, the present authors are aware that the coming of Christianity means that some Shona peoples have discarded this particular world view. This paper thereof is focused only for those that still subscribes to Shona traditional world view.

The spirit world comprises of ancestors, spirits and Mwari (God in Shona) all in a hierarchy. Mwari is not only ultimate to both the natural and human worlds but provides the moral sanction for all creation (see figure 1 below). Within this framework, peace is described in terms of cosmic order and harmony which is divinely sanctioned. In their conception, no individual person under normal circumstance would dare to cause disruption to the perceived order and harmony. Harmony is construed as the indivisible interdependence between human beings and the spirit world. While order is perceived as the unavailability of disruptive circumstances or events such as violation of standards of behaviour such as theft, murder or adultery.

In this web of interdependence, human beings have the responsibility to respect the universal cosmic order which is divinely sanctioned (Onah, n.d.). In the words of Masaka and Chemhuru (2011:134): "violation of taboos is perceived as direct provocation of spiritual forces which are the custodians of the moral code." There is a body of literature which confirms that violation of the divinely sanctioned moral code by human beings had dire consequences to villains (Chigidi, 2009; Masaka and Chemhuru, 2011; Onah, n.d.). The role of spirits in influencing behaviour is beyond the scope of this paper.

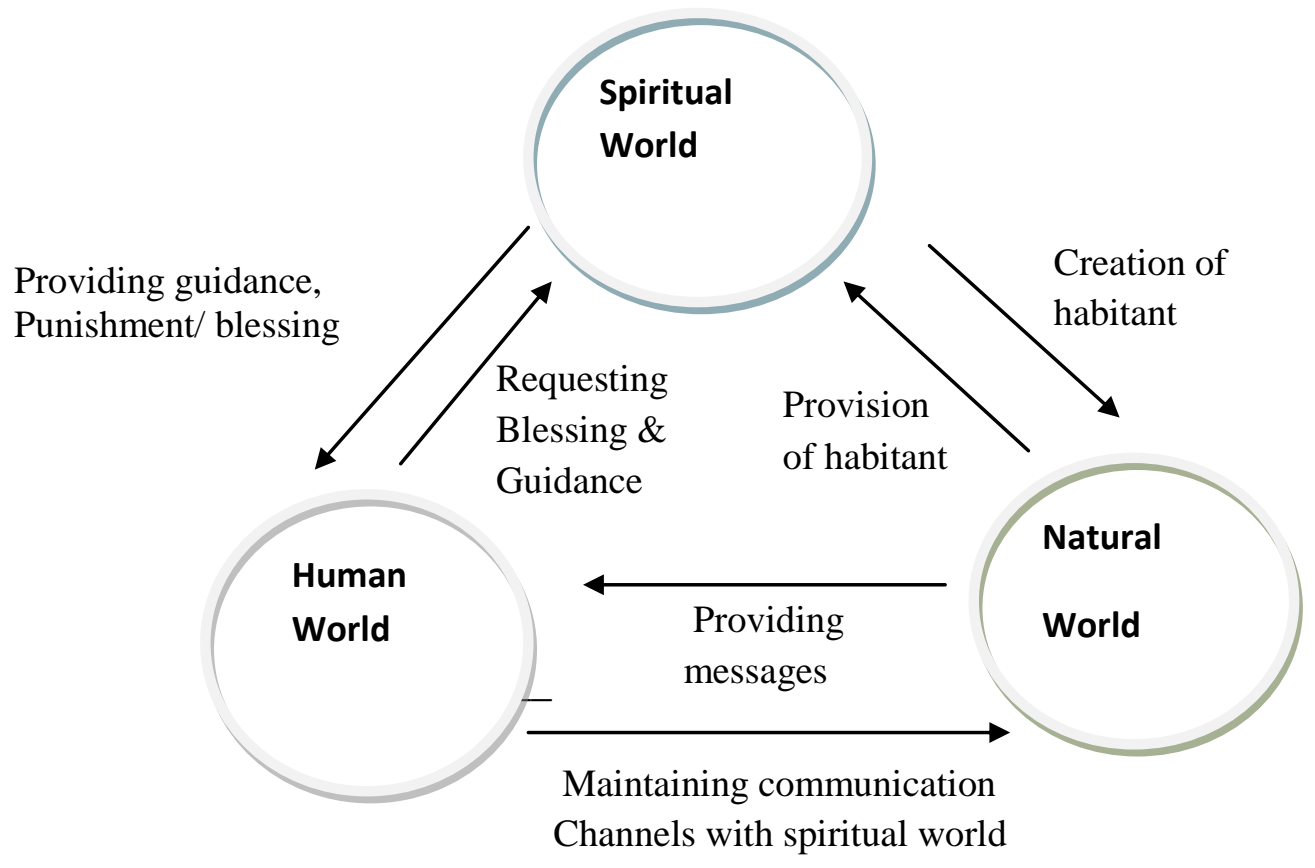

Figure1. The Shona cosmovision

Source: Haverkort et al (2003:142)

The figure above illustrates the concept of interdependence, the source of Shona people's moral system and how individual members of the community fits into it. This belief is not unique among the Shona peoples of Zimbabwe. In fact it is prevalent among most traditional societies in Africa. Onah (n.d) outlines succinctly how peace is conceived in African societies: 
Peace is not an abstract poetic concept but rather a down-to earth and practical concept ... [it is]...conceived not in relation to conflict and war but in relation to order, harmony, and equilibrium. It is a religious value in that the order, harmony and equilibrium in the universe and society is believed to be divinely established and the obligation to maintain them is religious. It is also a moral value since good conduct is also required of human beings if the order, harmony and equilibrium are to be maintained.

The point is peace in African societies is tilted towards the religious dimension and is understood in terms of social harmony, co-existence, tolerance and unity among other virtues. Social harmony among the Shona is better explained by the prime word for peace rugare. Rugare finds expression in virtues such as kunzwana (mutual understanding), kugarisana (peaceful co-existence), kuwadzana (civic fellowship), hushamwari (friendship), kudyidzana (mutual desire to promote each other's happiness and self-actualization), mushandirapamwe (cooperation) among others (Chimuka, 2001:33). These moral values are indispensable today just as they were in the Shona past. Their capacity to inculcate commendable behaviour renders them relevant even today.

In literature, the approach to the concept of peace is categorized into two different paradigms which are: the numinar and popular paradigms (Rinehart, 1989; 1995; Jeong, 2000). What each paradigm says about human nature is what distinguishes the two. In the former, human nature is not perceived as aggressive and conflictual. Competition and coerciveness are perceived as secondary. Accordingly, his paradigm emphasizes intra- and interpersonal peace which relates to: "oneness, harmony, and tranquillity" which include "a larger other, God, society and nature" (Rinehart, 1989: 386; 1995: 382). This paradigm is informed by teachings from Judaism, Hinduism, Buddhism, Baha'i, Christianity and African traditional religions (ATR). In other words, Shona understanding of peace can be classified under the numinar paradigm of peace from an academic point of view. Proponents of this paradigm include Lao Tzu, Buddha and Jesus, Mbuya Nehanda among others (ibid.). Mbuya neHanda was described as the symbol of peace among the traditional Shona (Kazembe, 2010) and this peace fell within the numinar peace paradigm. The numinar paradigm is what is represented on figure 1 above. Its thrust is on intrapersonal harmony which manifests through interpersonal interactions.

The popular paradigm, as the name depicts represent a modern conception of peace which asserts that human beings are motivated by self- interests and therefore, conflict is perceived as inevitable. This paradigm is historically linked to western philosophical and political thought (for example, Thomas Hobbes who viewed human nature as motivated by self interests) which in the recent past has been largely popularized by $21^{\text {st }}$ century scholars such as Kenneth Boulding and Johan Galtung ( see Rinehart, 1989).

Under the popular paradigm both peace and violence have twin ideas: negative and positive peace; direct and structural violence. Direct violence is the infliction of physical harm, injury or casualties sustained during an armed conflict or war. While structural violence is harm, death or constrain posed by policies and structures on certain individuals and groups from realizing their full potential (Simmons, 2010).

Negative peace which is normally characterised by the absence of direct violence is potentially the breeding ground for structural violence. Positive peace is the absence of all forms of violence both visible and non-visible and the realization of all values such as economic, social justice and human rights (Akerlund, 2005). Thus, the popular paradigm focuses on structural change as an approach to achieving and sustaining positive peace.

In a nutshell, the two paradigms are not complete opposites but they complement each other in that the numinar represents intra- and interpersonal visions for peace which should be characterized by oneness, harmony and equilibrium as realities that should be sought diligently at micro level. Whereas, the popular paradigm which represents institutionalized peace at macro -level emphasizes values such as economic equality, social justice, human rights, and harmony, which are critical for sustainable peace (Jeong, 2000). This paper is interested with the micro-level conception of peace, hence the focus on the taboo system. Taboo system is oriented towards intra and interpersonal harmony and equilibrium which when blended with environmental, social and economic justice can result in harmonious relationships within and between individuals and groups.

While the Shona taboo has environmental, economic, social and political dimensions, this paper is interested with the social dimensions of taboos. Taboos were bent on promoting moral virtues such as 
respect, tolerance, accommodation or co-existence (to not provide an exhaustive list). These virtues sustained interpersonal relations between individuals and the community members.

Nevertheless, in spite of the significant role played by the taboo system in promoting and sustaining peace in traditional communities, there seems to be a complete disregard of taboos by modern communities. The seemingly undermining of taboos can be attributed to the emergence of modernization which undermined indigenous moral value systems. This was due to various changes experienced by traditional communities as they adopted western values, customs and lifestyles which were more oriented towards individualism at the expense of communitarianism (Kilonzo et al 2009).

A modernized community is that which has a monitory economy, industrialized, developed technology involving rural mechanization, improved transport and communication networks and mass media (such as radio, televisions and satellite networks). Traditional Shona extended family and neighbour relations have also been affected by eventual effects of modernization which include but not limited to individualism, competition and nucleus household units (Adams, 2002).

Nevertheless, in pre-colonial era, as much as Shona traditional communities experienced this brunt of diversity, they did not allow the attitude of collectivism to be overshadowed by individualism and competition. This is contrary to modern Shona communities, where people are divided along political differences. In that case, efforts to resuscitate and re-institutionalise taboos can potentially help to inculcate behaviour that accommodates and respects diversity in modern Shona communities. So following this realization this paper argues that taboo system can be blended with contemporary systems in order to create a moral virtuous community in Zimbabwe.

\section{METHODOLOGY}

The paper is based on literature and insider participant observation sources. The writers grew up in one of the rural southern Shona communities in Zimbabwe and have intimate knowledge on the moral implications of the taboo system and its role as a murder deterring mechanism in the traditional Shona community.

\section{FINDINGS AND DISCUSSION}

There is extensive literature, which confirms that customary law was part of the common heritage of traditional Shona people (Gelfand, 1999:110-118; Gombe, 2006:51, 59, 128, 210-212). According to Reynolds and Russel (1983:15), customary law consist of desirable habits and customs which have become part of the life of a particular people group. These habits and customs may be based on religious beliefs and practices among other sources. A typical example of Shona customary law and their subsequent peaceable values include but not limited to:

(1) Honor your father and mother. The values embedded in this customary law include respect, social harmony and peace. Cordial harmony between parents and children is its major objective.

(2) Chitema hachidzorwe (do not take revenge). The values of this law are non-revenge, forgiveness, reconciliation, tolerance and accommodative. Instilling positive interpersonal relationships is its major objective.

(3) Usaba (do not steal). Values carried by this law include respecting other people's properties, honesty, hard work and co-existence. The major objectives are to instill an attitude of honesty, dependability, faithfulness, trustworthiness and hard work.

(4) Usuraya (do not kill). Values that go along with this law are respect for life, treating each individual person as a human being, nonviolence and cordial harmony. This law seeks to instil a culture of nonviolence and that human life is sacred and therefore needs to be protected and persevered.

Thus, customary law served as a broader framework against which peaceable social and values were traditionally transmitted through the taboos system and other institutions which are beyond the scope of this paper. For purposes of illustration, I have singled out taboo system which has endured up to this day even among the modern Shona so we can make sense of a system of peaceable values and expectations of Shona communities. 
In matters relating to respect for human life, there was a Shona taboo which says: usauraya munhu unoita ngozi (do not kill another person as you and the entire family members would suffer the dire consequences of an avenging spirit) (Mawere and Kadenge, 2010:32). A number of authors concur that violation of this taboo was associated with serious consequences both for the offender and his/her kits and kin (Chigidi, 2009; Mawere, 2010; Mawere and Kadenge, 2010).

As a result of the influence of this particular taboo, it appears, there were very few incidences related to wilful killing of another person, which is suggestive of the fact that, besides being a code of conduct, this particular taboo served as a murder deterrence mechanism within the community. On a positive note, this taboo helped to promote harmony, order and equilibrium thereby sustaining peace in the community (Mawere and Kadenge, 2010). It can thus, be deduced that peace was sustained due to respect for life, the rights of both individuals and groups as a result of this taboo.

In matters relating to gender-based violence against women, there was a taboo which says: usatuka, kurova kana kuuraya mai vako, unotanda botso (do not scold, beat or kill your mother as this would result in your suffering from an avenging spirit of your mother/ societal denial if the mother is alive) (Mawere and Kadenge, 2010:33). In the traditional Shona society, the term mother is used to refer to both biological and all female siblings and cousins. The sole objective of this taboo was to mitigate violence against female siblings and cousins.

By avoiding both physical and psychological violence against female siblings peace was promoted and sustained in the communities. Thus, the issue of gender-based violence which has in recent years is becoming a matter of great concern was put under control by taboos and communities inculcated this disposition. To this end, it can thus be concluded that, in the traditional Shona community, people had the idea of what constitutes good behaviour and "its importance in enhancing a good life devoid of the vices that would render society chaotic" (Masaka and Chemhuru, 2001:132). Against this backdrop, this article argues that, although the taboo system is perceived as non-scientific and unsuited for contemporary issues, from a post-modernistic point of view, it is in fact, as we perceive it, a potential resource for inculcating positive behaviour that promotes and sustain peace among the southern Shona communities.

Since the world has now become a village, communities are now becoming more and more heterogeneous. In that light; it may not be unreasonable to argue that the practice of traditional virtues, taboos in particular, is becoming harder than in the recent past because community members were not remotely located from each other. Kilonzo and colleagues loudly echoed that: "the erosion of the taboo system in most African communities, however, has meant the disruption of societal brotherhood" (2009:49). Even though, traditional communities need not to despair given that people's behaviour is influenced by tradition, modernity and religion. More so, the Shona tradition is inseparably bound together with religion, therefore, it may be appropriate to adapt relevant taboos to meet contemporary challenges such as modernity with an eye view to promote co-existence.

\section{LESSONS LEARNT}

Chimuka (2001) asserts that taboo system was developed in order to address the needs of the community such as: hushamwari (civic friendship), mushandirapamwe (co-operation) and kugarisana (peaceful co-existence) among other virtues. In the same way, modern Shona communities may need to re-consider taking the taboo system on board, revive and re-develop the traditional moral values that are more inclined to promoting peace within communities. This calls for concerted effort from the cross-section of the community to begin to prioritise local knowledge, and adapt it to suit the contemporary challenges one of which involves building sustainable harmony not only among the Shona communities but even across the globe. What is clear from the discussion above is that:

$\checkmark$ Taboos are closely linked to peaceable values such as love, co-existence, tolerance and respect and accommodation.

$\checkmark$ People's behaviours are often influenced by religious traditions meaning that religious traditions has a bearing to everyday life of a particular people group and therefore cannot be regarded as obsolete.

$\checkmark$ Electoral violence is symptomatic of the disregard of the taboo system by modern Shona communities making them ease prey to political manipulation by some political elites. 
$\checkmark$ The problem of electoral violence calls for more than just efforts by government to enforce law and order to address this menace but an appeal to the taboo system which is not based on law enforcement agents but respect for the in-born humanitarian seed.

\section{CONCLUSIONS AND RECOMMENDATIONS}

From the above argument, it is clear that if taboos revitalized peace can be promoted and sustained among the Shona communities. This taboo do not kill another person is crucial in inculcating disposition that makes Shona communities well disposed to respecting the sacredness of human life regardless of race, political affiliation or status. The fact that this particular taboo has survived the test of time as a murder deterrent mechanism is enough evidence to argue that it can also be used to inculcate positive behaviour that does not condone violence among the Shona communities. As highlighted already, the unprecedented levels of violence especially among Shona dominated communities in Mashonaland, Manicaland and Masvingo provinces confirm that community values, norms and customs are continuing to deteriorate causing community members to experience unhealthy living conditions.

Another taboo of particular importance is that which is related to gender-based violence: do not scold, beat or kill your mother as this would result in your suffering from an avenging spirit of your mother/ societal denial if the mother is alive. This taboo is more inclined to promoting peaceful co-existence between men and women. Therefore, using existing community structures, it may be appropriate to revive the taboo system. Finally, in this age where violence is seemingly becoming humanity's second nature, the taboo system has the potential to effectively promote and sustain peace among the Shona communities in Zimbabwe

\section{REFERENCES}

[1] Adams, B. N. 2002. Kinship systems and adaptation to modernization. Studies in Comparative International Development, pp.47-62.

[2] Akerlund, A. 2005. Transforming conflicts and building peace. Sida Studies No.13.

[3] Alexander, J. and Tendi, B. M. 2008. A Tale of Two Elections: Zimbabwe at the Polls in 2008. Bulletin No. 80, Winter,

[4] Bamfo, N. 2010. Mugabe's 2008 reelection victory: issues and debates. African and Asian Studies, Vol. 9, Issue 1, pp.105-127.

[5] Bufacchi, V. 2005. Two concepts of violence. Political Studies Review, Vol. 3, Blackwell Publishing, pp. 193-204.

[6] Chigidi, W. L. 2009. Shona taboos: the language of manufacturing fears for sustainable development. The Journal of Pan African Studies, Vol. 3, No.1, September, pp. 174-188.

[7] Chimuka, T. A. 2001. Ethics among the Shona. Zambezia, Vol.XXVII, No.1, pp.23-37.

[8] Fischer, J. 2002. Electoral conflict and violence: a strategy for study and prevention. IFES White Paper. 5 February, International Foundation for election Systems (IFES).

[9] Fortune, G., 1980, (ed.), Ngano. Vol. 1, Harare: Mecury Press.

[10] Gelfand, M. 1999. The Genuine Shona: survival values of an African culture. Gweru: Mambo Press.

[11] Gelfand, M., 1965, African background: the traditional culture of the Shona-speaking people. Cape Town: JUTA and Company.

[12] Gombe, J. M. 2006. Tsika dzavaShona. Harare: College Press

[13] Harpviken, K., B., and Skara, B., A., 2003, Humanitarian mine action and peace building: exploring the relationship. Third World Quarterly, vol. 24, No.5, pp.809-822.

[14] Jeong, H. 2000. Peace and conflict Studies: an introduction. Aldershot: Ashgate Publishing Ltd.

[15] Kabweza, M, 2002, Pasichigare. Gweru: Mambo Press.

[16] Kazembe, T., 2010, Shona traditional gatherings. The Rose Croix Journal, Vol. 74, pp.52-74. 
[17] Kilonzo, S., M., Kurgat, S., G., and Omare, S., G., (2009), The Role of taboos in the management of natural resources and peace-building: a case study of the Kakamega forest in western Kenya. Africa Peace and Conflict Journal, Vol.2, No. 1, University for Peace Africa Programme, June, pp.39-54.

[18] Masaka, D. and Chemhuru, M. 2011. Moral dimensions of some Shona taboos (zviera). Journal of Sustainable Development in Africa, Vol.13, No.3, pp.132-148.

[19] Mawere, M. and Kadenge, M. 2010, Zvierwa as African IKS: epistemological and ethical implications of selected Shona taboos. Indilinga-African Journal of Indigenous Knowledge Systems, Vol. 9, No. 1, pp.29-44.

[20] Onah, G. I. Undated. The Meaning of peace in African traditional religion and culture. Rome: Potnifical Urban University. http://www.afrikaword.net/afrel/gddionah.htm. Accesed: 30/09/11.

[21] Reeler, T. 2008. Subliminal terror? Human rights violations and torture in Zimbabwe during 2008. Centre for the study of violence and reconciliation. Braamfontein.

[22] Reynolds, D. A. and Russell, J. A. 1983. An introduction to law. Harare: Government Printer

[23] Rinehart, M. 1989. Towards better concepts of peace. Working paper 89. Conflict Resolution Consortium, Boulder: University of Colorado.

[24] Ibid., 1995. Understanding the concept of "peace": a search for common ground. Peace and Change, Vol. 20, No. 3, July, Peace History Society and Consortium on Peace Research, pp. 379-396.

[25] Simmons, D. 2010. Structural violence as a social practice: Haitian agricultural workers, antiHaitiansm, and health in the Dominican Republic. Human Organization, Vol. 69, No. 1, The Society for Applied Anthropology, pp.1-106.

[26] States in transition Observatory (SITO), 2008. Defining violation: political violence or crimes against humanity? IDASA.

[27] Tadjoeddin, M. Z. 2011.Electoral conflict and the maturity of local democracy in Indonesia: testing the modernisation hypothesis. (Forthcoming in, Journal of the Asian Pacific Economy.) Downloaded from: www.uws.edu.au/staff_profiles/uws_profiles/ doctor _zulfan. Accessed: 17/12/14.

[28] Tatira, L., (2000), Zviera zvavaShona. Gweru: Mambo Press.

[29] Teshome, W. 2009. Electoral violence in Africa: experience from Ethiopia. World Academy of Science, Engineering and Technology, Vol. 3, pp.7-28.

AUTHORS' BIOGRAPHY

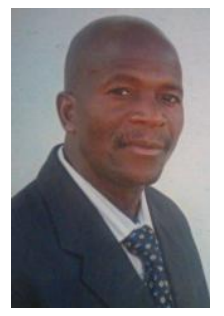

Dr.Norman Chivasa, having graduated with a $\mathrm{PhD}$ in Conflict Resolution Studies with the University of KwaZulu-Natal, Durban, South Africa in 2016. He is currently a post doctoral fellow with the same University. He has published a book under the title: 'The nature, extent causes and consequences of conflicts involving pastors' through LAMBERT ACADEMIC PUBLISHING. [ISBN N0. 978-3-659-16246-6]. He has also co-published four (4) peer reviewed Journal articles. He has also written two modules for the Zimbabwe Open University under the titles: BSDS 301: Community Rehabiliation; MSPL 521: Theory and Practice of Leadership. Norman Chivasa is a holder of a Masters in Conflict Resolution \& Peace Studies with University of KwaZulu-Natal, 2008; a Postgraduate Diploma in Development studies with Lupane state Univeristy, 2010; a Bachelor of Theology, 2004; Bachelor of Theology (Hons) with Theological college of Zimbabwe, 2005; and a diploma in theology with Living waters Theological Seminary, 1997. He is currently associated with Southern Peace Review Journal which is run by the Southern Institute of Peace building (SIPD), where he is currently serving as assistant editor.

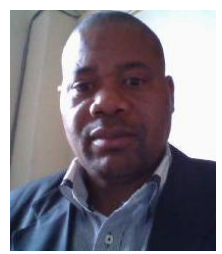

Mr Andrew Mukono, is a PhD Candidate in Political Science with the University of South Africa (UNISA). He is currently lecturing in the Department of Peace, Leadership and Conflict Resolution under the Faculty of Applied Social Sciences with the Zimbabwe Open University (ZOU). He holds the following qualifications and publications. 


\section{Qualifications}

Master of Science in Peace, Leadership and Conflict Resolution (Zimbabwe Open University), Bachelor of Arts (English and Communication Studies - Zimbabwe Open University), Bachelor of Science Honours Politics and Administration (University of Zimbabwe) and Diploma in Personnel Management (Institute of People Management Zimbabwe) (IPMZ)).

\section{Publications}

1. Mukono,A. (2015); An Evaluation of the role of women in Conflict Resolution processes in Zimbabwe from 2008 to 2013: A Case Study of Marlborough Suburb, Harare; India; The International Journal Of Humanities \& Social Studies, Volume 3, Issue 4, pp 261-273;ISSN 23219203

2. Hlatywayo, L. Mukono, A and Mukashi, M. (2015); Managing Governments of National Unity: Reflections of the Zimbabwean Joint Monitoring and Implementation Committee (JOMIC); India; The International Journal Of Humanities \& Social Studies, Volume 3, Issue 4, pp 273-278; ISSN 2321-9203

3. Mukono,A and Hlatywayo, L.(2015); An Evaluation of the Relationship between Zimbabwe's Land Reform Programme and Poverty Alleviation: A Case Study of Nyabira Area in Mashonaland West Provinc; India; The International Journal Of Humanities \& Social Studies, Volume 2, Issue 12, pp 318-326; ISSN 2321-9203

4. Muyambo P. Mukono, A (2014), An Assessment of the Effectiveness of Non Governmental Organisations (NGOs) Approaches in Reducing Vulnerability of Rural Female Headed Households (FHH) to Disasters in Chimanimani District; India; The International Journal of Humanities and Social Studies 2 (11) pp267-277; ISSN 2321-9203

5. Hlatywayo,L. Mukono, A (2014); Corruption in Zimbabwe: The Causes; India; The International Journal of Humanities and Social Studies, 2 (9), pp266-271; ISSN 2321-9203

6. Magede A.E. Mukono A. (2014) An Evaluation of the Impact of the Zimbabwe Land Reform Programme on Female Farm Workers: A Case Study of Nyabira in Mashonaland West Province; India; International Journal of Science and Research, 3 (9), pp282-290; ISSN 23197064

7. Hlatywayo,L. Mukono,A. (2014) An Evaluation of the Zimbabwean Government of National Unity (2008-2013); India; International Journal of Science and Research, 3 (8) online; ISSN 23197064

8. Hlatywayo, L., Mukono A. (2014) The Responsiveness of ODL Services to the Needs of Students with Disabilities at Zimbabwe Open University: The Case of Harare Region; India IOSR Journal of Humanities And Social Science, 19 (8) pp 51-57 ISSN 2279-7064 